\title{
Karlmaður með lækkað natríum, slappleika og megrun vegna æxlis í heiladingli
}

\author{
Guð̃ni Arnar Guð̃nason, Sigríour Pórdís Valtýsdóttir, Trausti Valdimarsson, Stefán Porvaldsson, Porvaldur Magnússon
}

\section{ÁGRIP}

Tæplega áttræður karlmaður var lagður inn á sjúkrahús til endurhæfingar eftir aflimun á fæti premur mánuð̌um fyrr. Vegna vöðvarýrnunar og slappleika var fyrirhugaðri pjálfun með gervilim frestað. Líðan sjúklings hrakaði jafnt og pétt og rannsóknir sýndu meiri lækkun á natríum í sermi. Upp- vinnsla leiddi í ljós skort á heiladingulshormónum sem reyndist stafa af æxli í heiladingli. Eftir að uppbótarmeðferð með kortisóli, pýroxíni og testósteróni var hafin lagađist ástand sjúklings til muna og natríumgildi leiðréttust.
Höfundar eru allir læknar og vinna á Heilbrigðisstofnun Vesturlands, Akranesi.

Fyrirspurnir: Guðni Arnar Guðnason gudni.gudnason@hve.is

\section{Tilfelli}

78 ára karlmaður með sögu um útæðasjúkdóm og sykursýki af tegund 2 var staddur erlendis pegar hann braut hægri lærleggsháls eftir fall. Skipt var um mjaðmalið á sjúkrahúsi en mánuði síðar komst drep í hælsárið og purfti að taka af hægri fótlegg neðan við hné. Vegna prekleysis sjúklings var ekki hægt að hefja sjúkrapjálfun. Blóðrannsóknir á honum sýndu lækkað natríum í sermi, 128 mmól/lítra, en ekki voru gerðar frekari rannsóknir á blóðsöltum. Sjúklingnum voru gefnar salttöflur og hafin sjúkrapjálfun sem gekk hægt. Premur mánuðum síðar var hann fluttur á sjúkrahús til frekari endurhæfingar. Við komu var sjúklingur sljór og ekki áttaður að fullu. Hann var 1,75 m að hæð og vó $54 \mathrm{~kg}$, eða $9 \mathrm{~kg}$ léttari en við mælingu tveimur árum fyrr. Við skoðun sást áberandi vöðvarýrnun. Röntgenmynd af lungum og tölvusneiðmynd af höfði voru eðlilegar, og slitbreytingar og beingisnun sáust á röntgenmyndum af hægra hné. Sjúklingur var áfram preklaus og hafði litla matarlyst. Endurteknar mælingar sýndu lækkandi natríum í sermi, úr 135 í 125 mmól/ lítra. Talið var að sjúklingurinn hefði heilkenni óviðeigandi losunar pvagskerðihormóns (SIADH, syndrome of inappropriate ADH secretion) og voru fengnar tölvusneiðmyndir af heila, brjóstholi og kviðarholi en pær voru taldar eðlilegar. Nokkrum dögum síðar mældist natríum í sermi aðeins 119 mmól/lítra og sjúklingurinn var orðinn mjög preklítill og kvartaði yfir ógleði. Fengin var morgunmæling á kortisóli í sermi sem sýndi verulega lækkað gildi, eða 48 nmól/1 (viðmiðunargildi 170-550 nmól/l) og vaknaði pá grunur um vanstarfsemi á heiladingli. Frekari blóðrannsóknir eru sýndar í töflu I, en pær sýndu lækkuð gildi pýroxíns (fT4) og príjoðpýroníns (fT3) og testósteróns, LH og IGF-1 (tafla I). FSH (follicular stimulating hormone, kynfrumnakveikja) var nálægt neðri mörkum, ACTH (adrenocorticotropic hormone, nýrilbarkarhvati)og TSH (thyroid stimulating hormone, skjaldvakakveikja) voru innan eðlilegra marka en prólaktín lítillega hækkað.

Sterkur grunur vaknaði um sjúkdóm í heiladingli sem ylli skertri framleiðslu heiladingulshormóns.
Segulómun af tyrkjasöðli (mynd 1) sýndi 1,4 x 1,3 x 1,3 cm fyrirferð í heiladingli sem óx upp að sjóntaugavíxlum (chiasma opticum) og innri hálsslagæð hægra megin. Sjónsviðsmæling sýndi væga skerðingu gagnaugamegin á vinstri hlið. Útlitið var talið samrýmast góðkynja kirtilæxli í heiladingli. Eftir samráð við heilaskurðlækna var ákveðið að bíða með skurðaðgerð og endurmeta æxlið premur mánuðum síðar.

Gefið var ACTH (Synacthen) í vöðva sem hækkaði kortisól í sermi úr 172 í 399 nmól/l eftir 30 mínútur og í 446 nmól/l eftir klukkustund. Svörunin var metin ófullnægjandi en óvart hafði verið gefinn of hár skammtur af nýrilbarkahvata, 1000 ug í stað 250 ug. Hafin var meðferð með hýdrókortísóntöflum og skömmu síðar einnig með pýroxíni (Levaxín) og testósteróni.

Eftir lyfjameðferð hurfu einkenni sjúklings á nokkrum vikum. Prek og matarlyst jókst og preyta og sljóleiki gengu til baka. Premur vikum síðar mældist pýroxín í sermi 15,3 pmól/l í stað 10,6 pmól/l áđur, og natríum hækkaði úr 122 mmól/l í 136 á 5 dögum. Hann pyngdist um $12 \mathrm{~kg}$ á tveimur mánuðum, gat hafið endurhæfingu, lært að nota gervifót og var útskrifaður á dvalarheimili. Endurteknar segulómanir premur og 12 mánuðum eftir innlögn sýndu óbreytta stærð heiladinguls og ekki höfðu komið fram nýjar sjónsviðstruflanir. Pví var ákveðið að bíða með skurðaðgerð.

\begin{tabular}{lcl}
\hline \multicolumn{3}{l}{ Tafla I. Eðlileg gildi eru sýnd innan sviga. } \\
\hline ACTH & 20 & $(0-46 \mathrm{ng} /$ lítra $)=$ nýrilbarkahvati \\
\hline TSH & 1,41 & $(0,3-4,2 \mathrm{mU} /$ lítra $)=$ skjaldvakakveikja \\
\hline fT4 & 10,6 & $(12-22 \mathrm{pmól} /$ lítra $)=$ týroxín \\
\hline fT3 & 3,1 & $(3,5-6,7$ pmól/lítra $)=$ príjoðtýronín \\
\hline LH & 0,6 & $(1,7-9,0$ U/lítra $)$ \\
\hline FSH & 1,7 & $(1,5-12$ U/lítra $)$, \\
\hline Testósterón & 0,09 & $(6,7-25,7$ nmól/lítra $)$ \\
\hline IGF-1 & 43 & $(59-177$ míkrógrömm/lítra $)$ \\
\hline Prólaktín & 33,4 & $(4,5-21,0$ míkrógrömm/lítra $)=$ mjólkurhormón
\end{tabular}

LH=gulbúskveikja, FSH=kynfrumnakveikja, IGF-1=Insulin-like Growth Factor-1 


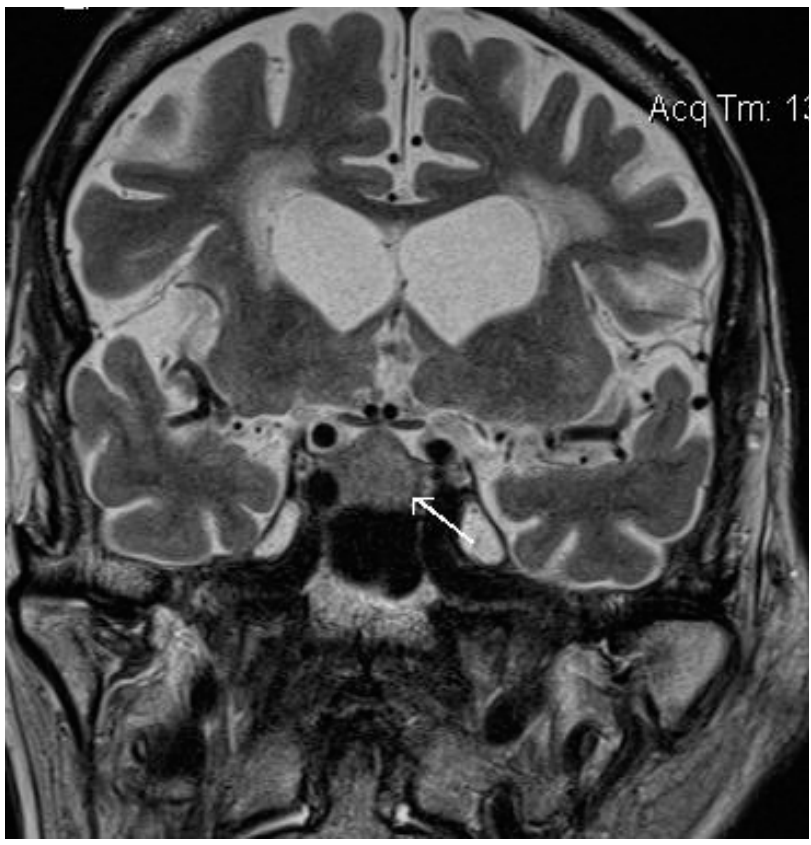

Mynd 1. $1,4 \times 1,3 \times 1,3 \mathrm{~cm}$ fyrirferð í heiladingli.

\section{Umræður}

Góðkynja kirtilæxli er algengasta fyrirferðin í heiladingli ${ }^{1}$ og eru æxli yfir $1 \mathrm{~cm}$ í pvermál skilgreind sem stórkirtilæxli en önnur sem smákirtilæxli. Pessi æxli eru ýmist seytandi eða ekki-seytandi. Mjólkurhormónsæxli (prolactinoma) eru algengust kirtilæxla, eða í um helmingi tilfella, síðan ekki-seytandi æxli (35-40\%), vaxtarhormónsseytandi æxli (8-9\%), nýrilbarkarhvata-seytandi (ACTH, 2-4\%) og loks skjaldvakakveikju-seytandi (TSH, 1-2\%). ${ }^{2}$ I pessu tilfelli var æxlið ekki-seytandi og olli algjörri vanstarfsemi á heiladingli (panhypopituitarism) með skorti á ACTH, TSH, LH og FSH. Pá eru blóðgildi viðkomandi hormóna lækkuð eða innan neðri helmings viðmiðunarmarka. Heiladingulsbilunin skýrist af beinum prýstingsáhrifum æxlisins á kirtilvefinn eða truflun á blóðrás til eða frá heiladingli. Niðurstöður Synacthen-prófs bentu til kortisólskorts en hæsta gildi yfir 550 nmól/1 er talið útiloka kortisólskort. ${ }^{3}$ Til að staðfesta greiningu kortisólskorts má einnig framkvæma insúlínpolpróf sem metur starfsemi allra hormóna í undirstúku-heiladingulsöxlinum. Loks benti lækkað IGF-1 til skorts á vaxtarhormóni, ${ }^{4}$ en til að staðfesta pað er gert insúlínpolpróf eða vaxtarhormónshvata- og arginín (GHRH+Arginine) próf. Hár aldur sjúklings var metinn sem frábending fyrir meðferð með vaxtarhormóni og var hugsanlegur vaxtarhormónsskortur pví ekki rannsakaður nánar.

Dópamín bælir framleiðslu mjólkurhormóns úr heiladingli en fyrirferð í heiladingli eða undirstúku geta hindrað pessa bælingu og skýrir pað væga hækkun mjólkurhormóns í pessu tilfelli. Pegar um er að ræða æxli sem framleiða mjólkurhormón er hækkun á mjólkurhormóni hins vegar mun meiri.

Hjá sjúklingum með ekki-seytandi stórkirtilæxli án brottfallseinkenna frá miðtaugakerfi eins og sjóntruflanir, er oftast beðið með skurðagerð og fylgst með sjúklingum með endurteknum segulómskoðunum af höfði og sjónsviðsmælingum. Annars er æxlið numið á brott í gegnum nef og gert gat á fleygholsbein (transsphenoidal) til að komast að æxlinu.

Algengasta orsök lækkaðs natríums í sermi er SIADH en skortur á kortisóli eða pýroxíni getur einnig valdið pessu. ${ }^{6}$ Skýringin er talin vera aukin losun á pvagskerðihormóni sem veldur vatnssöfnun í líkamanum og par með minni péttni natríums í blóði. ${ }^{5}$ Í pessu tilfelli liðu margir mánuðir par til undirliggjandi orsök natríumlækkunar greindist, en einkennin voru almenn eðlis, aðallega slappleiki og preyta. Spurning er hvort fylgikvilla beinbrots megi að einhverju leyti rekja til heiladingulsbilunar en máttleysi gæti hafa pátt í pví að sjúklingur datt og beinpynning stafað af skorti á vaxtarhormóni. Auk pess getur vannæring vegna hormónaskorts tafið gróandi sára eins og sykursýki sem sjúklingurinn var með.

Minnkað natríum í sermi er algengt vandamál á sjúkrahúsum og undirstrikar petta sjúkratilfelli mikilvægi pess að hafa kortisólskort í huga sem orsök.

Pakkir fá ritstjórn Læknablaðsins fyrir yfirlestur og úrbætur og Kristinn Grétar Harðarson fyrir aðstoð við myndvinnslu.

\section{Heimildir}

1. Jagannathan J, Kanter AS, Sheehan JP, Jane JA Jr, Laws ER Jr. Benign brain tumors: sellar/ parasellar tumors. Neurol Clin 2007; 25: 1231-49.

2. Raappana A, Koivukangas J, Ebeling T, Pirilä T. Incidence of pituitary adenomas in Northern Finland in 1992-2007. J Clin Endocrinol Metab 2010; 95: 4268-75.

3. Agha A, Tomlinson JW, Clark PM, Holder G, Stewart PM. The long-term predictive accuracy of the short synacthen (corticotropin) stimulation rest for assessment of the hypothalamic-pituitary-adrenal axis. J Clin Endocrinol Metab 2006; 91: 43-7.

4. Biller BM, Samuels MH, Zagar A, Cook DM, Arafah BM, Bonert V, et al. Sensitivity and specificity of six tests for the diagnosis of adult GH deficiency. J Clin Endocrinol Metab 2002; 87: 2067-79.

5. Reynolds RM, Seckl JR. Hyponatraemia for the clinical endocrinologist. Clin Endocrinol 2005; 63: 366-74.

6. Verbalis JG, Goldsmith SR, Greenberg A, Schrier RW, Sterns RH. Hyponatremia treatment guidelines 2007: expert panel recommendations. Am J Med 2007; 120: S1.

\section{ENGLISH SUMMARY}

\section{A 78 year-old man with hyponatremia, malaise and weight loss caused by a pituitary mass}

Gudnason GA, Valtysdottir ST, Valdimarsson T, Thorvaldsson S, Magnusson T

\begin{abstract}
A 78 year-old male was admitted for rehabilitation after a trans-tibial amputation three months earlier. Scheduled training with a prosthetic leg was postponed due to muscle atrophy and weakness. As the patient's status deteriorated, blood results showed worsening hypo-
\end{abstract}

natremia.Work-up revealed pituitary insufficiency caused by a pituitary mass. The patient's general health improved greatly and the hyponatremia corrected after hormonal replacement therapy with Hydrocortisone, Thyroxin and Testosterone was initiated.

Key words: hyponatremia, malaise, weight loss, pituitary insufficiency, pituitary adenoma.

Correspondence: Guðni Arnar Guðnason, gudni.gudnason@hve.is 